MARINADE Vol. 03(02) : $114-120$ (Oktober 2020)

e-ISSN : 2654-4415

online : http://ojs.umrah.ac.id/index.php/marinade

\title{
KULTIVASI Spirulina platensis MENGGUNAKAN MEDIA WALNE DALAM SKALA LABORATORIUM
}

\author{
Cultivation of Spirulina platensis Use Walne's Media in a Laboratory Scale
}

\author{
Aldil Fadli Ilhamdy ${ }^{\left.{ }^{*}\right)}$, Jumsurizal ${ }^{1)}$, Darwin ${ }^{1)}$, Yoka Farel Septian Tambunan ${ }^{1)}$ \\ 1) Jurusan Teknologi Hasil Perikanan, Fakultas IImu Kelautan dan Perikanan, \\ Universitas Maritim Raja Ali Haji
}

*Korespondensi: Aidilfadliilhamdy@gmail.com

Diterima : 30 September 2020; Disetujui : 26 Oktober 2020

\begin{abstract}
This research was conducted in three stages: the first, prepared seawater to be sterilized for 2 days, which had been added with diluted chlorine and Na-thiosulfate. The second was preparation for cultivation on a small scale and for scale up on a large scale. The third was haversting Spirulina platensis when the cell density was at the peak of the growth curve (Optical density more than 0,5). The purpose of this study was to know the growth pattern of Spirulina platensis microalgae use walne media and to determine the ideal density of the microalgae growth until yhe haverst process. The results of the growth rate of Spirulina platensis, which were scaled to a scale of 80 liters using walne media, experienced very good cell growth, this can be seen from the increase in the amount of optical density (OD), temperature, and increased $\mathrm{pH}$. achieve general standard values.
\end{abstract}

Keywords : Microalgae, Cultivation, Spirulina platensis,

\begin{abstract}
ABSTRAK
Penelitian ini dilakukan dalam tiga tahap: pertama melakukan persiapan air laut untuk disterilisasikan selama 2 hari yang dimasukkan klorin dan Na-thiusulfat yang telah diencerkan. Kedua persiapan untuk kultivasi di skala kecil dan scale up di skala besar. Ketiga melakukan pemanenan Spirulina platensis saat kepadatan sel berada pada puncak kurva pertumbuhan (Optical density lebih dari 0,5). Tujuan dari penelitian ini adalah untuk mengetahui pola pertumbuhan. Mikroalga Spirulina platensis menggunakan media walne dan untuk menentukan kerapatan angka ideal pada pertumbuhan mikroalga hingga sampai pada proses pemanenan. Hasil dari laju pertumbuhan Spirulina platensis yang di scale up dengan skala 80 liter menggunakan media walne mengalami pertumbuhan sel yang sangat baik, hal ini terlihat dari kenaikan angka Optical density (OD), suhu, dan $\mathrm{pH}$ yang mencapai nilai standar pada umum nya.
\end{abstract}

Kata kunci: Mikroalga, Kultivasi, Spirulina platensis,

\section{PENDAHULUAN}

Mikroalga merupakan jenis rumput laut atau alga yang berukuran mikroskopis dan merupakan organisme tumbuhan yang paling primitif berukuran seluler yang umumnya dikenal dengan sebutan fitoplankton. Mikroalga memanfaatkan energi matahari dan karbondioksida untuk keperluan fotosintesis sehingga mikroalga 
disebut sebagai produsen primer dengan waktu pertumbuhan yang cepat yaitu mulai hitungan hari sampai beberapa minggu (Sani et al. 2014) (Prasadi, 2018).

Bentuk tubuh Spirulina sp. yang menyerupai benang merupakan rangkaian sel yang berbentuk silindris dengan dinding sel yang tipis, berdiameter 1-12 mikrometer. Filamen spirulina hidup berdiri sendiri dan dapat bergerak bebas (Hariyati, 2008). Mikroalga Spirulina platensis merupakan mikroorganisme yang memiliki kandungan nutrisi lengkap, terutama kandungan protein yang tinggi menyebabkan mikroalga ini memiliki potensi yang besar untuk dimanfaatkan sebagai bahan pangan fungsional.

Spirulina $s p$. mengandung protein $60-71 \%$, lemak $8 \%$, karbohirdrat $16 \%$, dan vitamin serta 1,6\% Chlorophyll-a, $18 \%$ Phycocyanin, 17\% $\beta$-Carotene, dan $20-30 \%$ y-inoleaic acid dari total asam lemak (Robi, 2014). Spirulina sp. merupakan mikroalga yang banyak dikonsumsi oleh masyarakat karena memiliki nilai gizi yang tinggi serta bermanfaat bagi kesehatan. Spirulina $s p$. ini banyak dimanfaatkan dalam bioteknologi, obat-obatan, pakan ikan dan Spirulina sp. juga telah digunakan sebagai suplemen oleh penduduk Afrika sebagai sumber makanan tradisional (Christwardana et al. 2013).

Biomassa Spirulina platensis mengandung senyawa-senyawa yang diperlukan oleh tubuh manusia diantaranya protein $55-70 \%$, lipid $4-6 \%$, karbohidrat $17-25 \%$, asam lemak tidak jenuh majemuk misalnya asam linoleat (LA) dan gamma linolenat (GLA), beberapa vitamin contohnya asam nikotinat, riboflavin (vitamin B2), thiamin (vitamin B1), sianokobalamin (vitamin B12), mineral, asam-asam amino, karotenoid, klorofil dan fikosianin
(Christwardana et al. 2013).

Kandungan nutrisi Spirulina sp. yang lengkap terutama protein yang tinggi menyebabkan Spirulina sp. Memiliki potensi yang besar untuk dimanfaatkan sebagai sumber protein (Amanatin dan Nurhidayati, 2013).

Untuk mendapatkan nutrisi Spirulina platensis yang baik perlu dilakukan kultivasi hingga pada proses pemanenan yang tepat. Pemanenan Spirulina platensis dilakukan pada saat sel berada pada puncak kurva pertumbuhan (Optical density lebih dari 0,5$)$ dan pemanenan tersebut melalui metode filtrasi menggunakan planktonet atau nylon mesh sebagai penyaring.

Dengan pentingnya peranan nilai kandungan nutrisi dan pemanfaatan dari Spirulina platensis bagi kehidupan manusia dan beberapa organisme laut lainnya, maka media kultur yang tepat sangat penting dilakukan untuk mendapatkan nilai kandungan nutrisi yang maksimal. Oleh karena itu penelitian ini bertujuan untuk mengetahui bagaimana pola pertumbuhan Spirulina platensis yang di kultur menggunakan media walne dan untuk mengetahui faktor-faktor yang dapat menghambat pertumbuhan dari Spirulina platensis.

\section{METODE PENELITIAN}

\section{Alat dan Bahan}

Alat yang digunakan untuk pertumbuhan mikroalga Spirulina platensis pada penelitian ini meliputi aquarium, aerator, tutup plastik transparan, toples, kuvet, gelas ukur, selang, batu aerasi, tisu, pipet, lampu, terminal, HSP 788 spektrofotometer health, alumunium foil, oven, infrared thermometer, light meter LX-104B, pH dan saringan plankton net.

Bahan yang digunakan untuk 
pertumbuhan mikroalga adalah bibit Spirulina platensis, vitamin $\mathrm{B}_{12}$, walne, alkohol, klorin, natrium thiosulfat dan aquades.

\section{Persiapan air laut untuk media kultur}

Persiapan air meliputi penyaringan dan sterilisasi air laut. Penyaringan dilakukan dengan menggunakan filter berdiameter $50 \mu \mathrm{m}$. Pengukuran salinitas dilakukan pada air laut yang telah disaring. Penambahan air tawar kemudian dilakukan bila salinitas air laut lebih dari 20 ppt. Air laut kemudian disterilisasi dengan menambahkan $\mathrm{NaOCl}$ 20 ppm dan diaerasi selama 24 jam. Netralisasi menggunakan 5 ppm Nathiosulfat dilakukan setelah sterilisasi selesai dan air kembali diaerasi selama 24 jam.

\section{Kultivasi dalam Media Walne}

Pada proses ini toples terlebih dahulu disterilkan menggunakan alkohol lalu dibilas menggunakan aquades dan dikeringkan. Kultur Spirulina platensis dilakukan dengan menggunakan 3 liter air laut ke dalam toples steril, kemudian ditambahkan media/nutrisi walne dan Vitamin $B_{12}$ masing-masing sebanyak 3 $\mathrm{mL}$, serta $300 \mathrm{ml}$ stok Spirulina platensis. Stok Spirulina platensis yang digunakan memiliki perbandingan 1:10 (1 bagian Spirulina dalam 10 bagian air laut). Setelah mencapai puncak kurva pertumbuhan di skala 3 liter, selanjutnya dilakukan scale up skala 30 liter dengan menggunakan perbandingan 13 liter air laut : 14 liter aquades kedalam aquarium yang telah disterilkan, lalu ditambahkan walne dan vitamin $B_{12}$ sebanyak $30 \mathrm{~mL}$, serta bibit Spirulina platensis $3000 \mathrm{~mL}$. Stok kultur pada scale up skala 30 liter yang sudah mencapai puncak kurva pertumbuhan selanjutnya di scale up dengan skala 80 liter menggunakan perbandingan 35 liter air laut : 37 liter aquades, kemudian ditambahkan walne, vitamin $\mathrm{B}_{12}$ sebanyak $80 \mathrm{~mL}$ dan bibit Spirulina platensis $8000 \mathrm{~mL}$. Selanjutnya aerasi setiap hari, intensitas cahaya yang digunakan berkisar 4000-6000 lux dan tutup aquarium menggunakan plastik transparan agar tidak terkontaminasi.

Optical density, suhu, $\mathrm{pH}$ dan intensitas cahaya di ukur setiap hari. Untuk pengukuran Optical density (OD) menggunakan alat spectrofotometer UV panjang gelombang $(\lambda) 620 \mathrm{~nm}$ dengan mode absorbansi. Pemanenan Spirulina platensis dilakukan saat kepadatan sel berada pada puncak kurva pertumbuhan (Optical density lebih dari 0,5) menggunakan plankton net sebagai penyaring dan dilakukan penjemuran dibawah sinar matahari sampai Spirulina platensis tersebut kering.

\section{HASIL DAN PEMBAHASAN}

Dibawah ini merupakan data pertumbuhan Spirulina platensis yang pengukuran Optical density menggunakan spektrofotometer UV dengan panjang gelombang $(\lambda) 620 \mathrm{~nm}$.

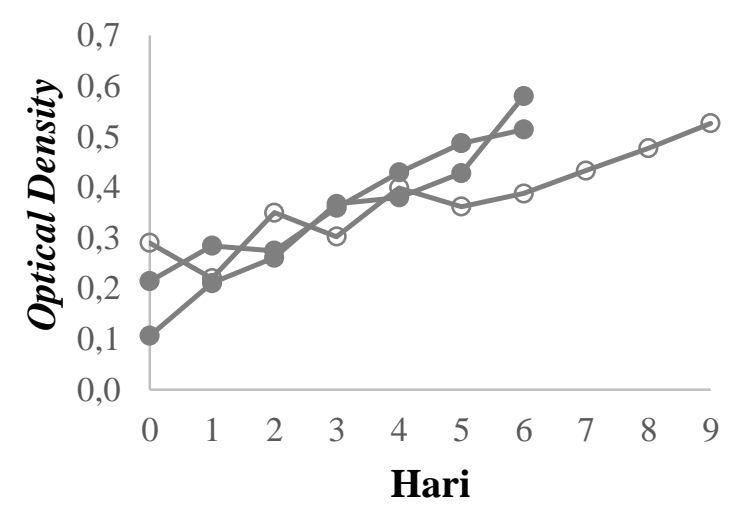

Gambar 1. Kurva Optical Density Pertumbuhan Spirulina platensis ( $\circ 3$ Liter; • 30 Lite;r • 80 Liter)

Pada Gambar 1 masing-masing kurva menunjukkan pertumbuhan pada media walne berlansung cepat dan 
masing-masing kurva mempunyai nilai Optical density yang berbeda. Pertumbuhan spirulina mengikuti pola umum seperti yang terjadi pada mikroorganisme lainnya, yakni melalui pembelahan sel sederhana tanpa tahap seksual maupun diferensiasi (Vonshak et al. 2002). Pada kurva tersebut untuk pertumbuhan di skala 3 liter mengalami fase pertumbuhan selama 9 hari dikarenakan dalam masa adaptasi dari air tawar ke air laut dan penyesuaian media yang digunakannya. Menurut Utomo (2005), Pertumbuhan pada fase awal terjadi lambat karena alokasi energi dipusatkan untuk penyesuaian diri terhadap media kultur dan untuk pemeliharaan sehingga hanya sebagian kecil bahkan tidak ada energi yang digunakan untuk pertumbuhan. Perbedaan nilai fase yang terjadi diakibatkan oleh perbedaan keberadaan kandungan nutrient pada media kultur sehingga mempengaruhi kualitas dan densitas sel (Widianingsih et al. 2008). Perhitungan laju pertumbuhan digunakan sebagai alat ukur kecepatan pertumbuhan sel mikroalga (Prayitno, 2006). Kurva pertumbuhan digunakan sebagai penentu saat mikroalga memasuki puncak kepadatan tertinggi.

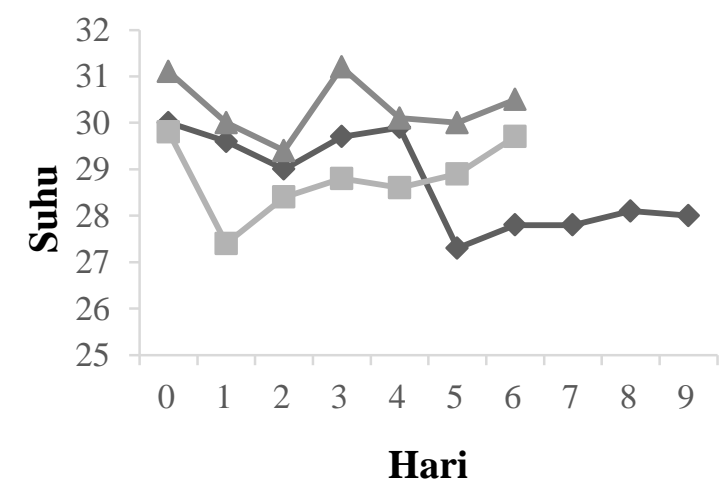

Gambar 2. Kurva Suhu Pertumbuhan Spirulina platensis (• 3 Liter; $\circ 30$ Liter; $\circ 80$ Liter)
Berdasarkan Gambar 2 untuk suhu pada penelitian ini kisaran kualitas air masih berada dalam kondisi yang baik untuk pertumbuhan Spirulina platensis. Suhu pada saat kultivasi mikroalga menggunakan media walne berkisar 30 31 ㅇ. Suhu secara langsung mempengaruhi efesiensi fotosintesis dan faktor yang menentukan dalam pertumbuhan. Menurut Hariyati (2008), temperature dan salinitas adalah faktor yang penting bagi penyebaran dan tingkah laku alga hijau biru. Kebanyakan alga hijau biru bersifat eurythermal dan euryhaline, sehingga pengaruh kedua faktor tersebut pada alga hijau biru relatif lebih kecil dibandingkan pengaruhnya pada alga jenis lain. Kisaran temperatur optimal bagi pertumbuhan Spirulina platensis yaitu antara $20^{\circ} \mathrm{C}-30^{\circ} \mathrm{C}$.

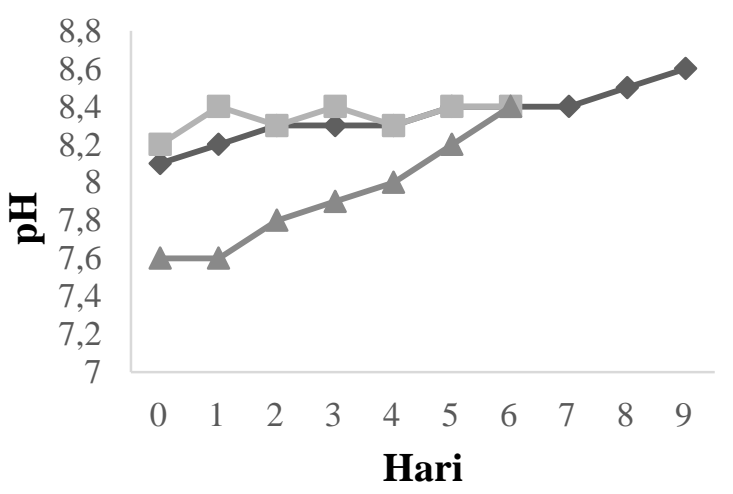

Gambar 3. Kurva pH Pertumbuhan Spirulina platensis (• 3 Liter; ○ 30 Liter; o 80 Liter)

Faktor lain yang sangat berpengaruh pada pertumbuhan Spirulina platensis adalah $\mathrm{pH}$. Pengontrolan $\mathrm{pH}$ medium sangat penting untuk menjaga keseimbangan pertumbuhan Spirulina platensis (Suminto, 2009). Menurut Suantika dan Hendrawandi (2009), kenaikan nilai $\mathrm{pH}$ disebabkan oleh bertambahnya ion hidroksil dalam kultur akibat asimilasi $\mathrm{CO}_{2} \mathrm{HCO}^{3-}$ oleh Spirulina 
platensis. Nilai $\mathrm{pH}$ pada semua kultivasi (gambar 3) berkisar antara 7,6 - 8,6, angka tersebut masih berada didalam kisaran toleransi Spirulina platensis dan selama dilakukan kultur tersebut nilai $\mathrm{pH}$ setiap hari meningkat sampai puncak kurva pertumbuhan. Kondisi tersebut didukung dengan pernyataan Santosa dan Limantara (2007), bahwa Spirulina $s p$. dapat tumbuh dengan baik pada $\mathrm{pH}$ kisaran 8-11. Nilai $\mathrm{pH}$ yang meningkat dalam media kultur disebabkan karena adanya penguraian protein dan senyawa nitrogen (Amanatin, 2006).

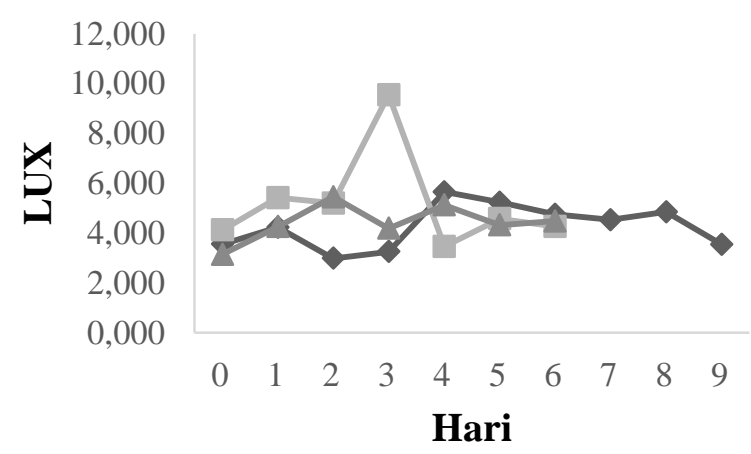

Gambar 4. Data Lux Pertumbuhan Spirulina platensis $(\bullet \quad 3$ Liter $\circ 30$ Liter $\circ 80$ Liter)

Cahaya merupakan faktor utama dalam pertumbuhan melalui proses fotosintesis. Waktu pencahayaan yang lebih pendek dan ketersediaan cahaya yang tidak cukup dapat menyebabkan rendahnya tingkat pertumbuhan mikroalga, sebaliknya waktu pencahayaan yang lebih banyak dengan intensitas cahaya yang optimum akan memberikan kesempatan mikroalga untuk tumbuh dan berkembang lebih cepat. Ekawati (2005) mengatakan bahwa cahaya merupakan sumber energi pada proses fotosintesis, oleh karena itu intensitas, kualitas dan priode penyinaran perlu diperhatikan. Intensitas cahaya berperan sangat penting, kebutuhannya sangat besar untuk kepadatan budidaya alga. Cahaya dapat berasal dari alam atau dari lampu. Untuk kultivasi di dalam ruangan biasa dilakukan dengan menggunakan lampu $\mathrm{TL}$ dengan intensitas cahaya 2500-4000 lux (Muyassaroh et al. 2018).

\section{KESIMPULAN}

Berdasarkan hasil dari penelitian ini dapat disimpulkan bahwa laju pertumbuhan Spirulina platensis yang di scale up pada skala 80 liter menggunakan media walne dan Vitamin $\mathrm{B}_{12}$ mengalami pertumbuhan kepadatan sel yang sangat baik, hal ini terlihat dari kenaikan angka Optical density (OD) mencapai 0,514 , suhu berkisar antara $30-31^{\circ} \mathrm{C}$ dan $\mathrm{pH}$ yang mencapai nilai standar pada umum nya yaitu 7-8. Faktorfaktor yang mempengaruhi pertumbuhan Spirulina platensis diantaranya yaitu penggunaan media walne dan Vitamin B12 sebagai pertumbuhan yang memiliki komposisi dan kadar nutrient yang lengkap sehingga dapat menunjang pertumbuhan Spirulina platensis lebih lama. Selain itu kondisi lingkungan, faktor internal seperti genetik memiliki pengaruh yang sangat penting dalam mempercepat pertumbuhan Spirulina platensis.

\section{DAFTAR PUSTAKA}

Addini, I. Saputra, D. Ilhamdy, F, A. dan Julianto, T. 2017. Pertumbuhan Mikroalga Spirulina plantensis yang Dikultur dengan Media Teknis. Intek Akuakultur. 1(1), 51-55.

Afriani, Sari. Uju. dan Setyaningsih, Iriani. 2018. Komposisi Kimia Spirulina platensis yang Dikultivasi dalam Fotobioreaktor dengan Fotoperiode berbeda.

Amanati, R, D. dan Nurhidayati, Tutik. 2013. Pengaruh Kombinasi Konsentrasi Media Ekstrak Tauge 
(MET) dengan Pupuk Urea terhadap Kadar Protein Spirulina $s p$. Jurnal Sains dan Pomits. 2(2), 2337-3520.

Bezerra, R.P, M.C. Matsudo, A. Converti, S.Sato, \& J. C.M. de Carvalho. 2007. Influence of Ammonium Chloride Feeding Time and Light Intensity on the Cultivation of Spirulina (Arthrospira) platensis. Biotech. and Bioengineering. 100 (2): 297-305.

Christwardana, Marcellinus, Muhamad Maulana Azimatun Nur, dan $\mathrm{H}$. Hadiyanto, 2012. Spirulina platensis: Potensinya Sebagai Bahan Pangan Fungsional. Jurnal Aplikasi Teknologi Pangan. 1 (2) : 1-4.

Chalid, S.Y., Amini, S., Lestari D.S. 2010. Kultivasi Chlorella, sp Pada Media Tumbuh yang Diperkaya Dengan Pupuk Anorganik Dan Soil Extract. Jurnal Valensi. 1 (6).

Effendi, H. 2003. Telaah Kualitas Air Bagi Pengelola Sumber Daya dan Lingkungan Perairan. Yogyakarta: Kasnisius.

Ekawati, A. W. 2005. Diktat Kuliah Budidaya Pakan Alami. Fakultas Perikanan Universitas Brawijaya. Malang.

Gouda, K. G. M., Kavitha, M. D., \& Sarada, R. (2015). Antihyperglycemic, antioxidant and antimicrobial activities of the butanol extract from Spirulina platensis Journal Food Biochem. 39, 594-602.

Hadiyanto, dan Maulana, A. 2012. Mikroalga: Sumber Pangan dan Energi Masa Depan. UPT UNDIP Press. Semarang. 1-18.

Hariyati, Riche. 2008. Pertumbuhan dan Biomassa Spirulina $s p$ dalam Skala Laboratoris. Bioma. 10(1) : 19-22.

Mitchell, S.A. \& A. Richmond. 2004. The use of rotifers for the maintenance of monoalgal mass cultures of Spirulina. Biotechnology and Bioengineering. 30
(2): 164-168.

Muyassaroh. Dewi, K.R. dan Anggorowati, D. 2018. Kultivasi Mikroalga Spirulina platensis dengan Variasi Pencahayaan Menggunakan Lampu TL dan Matahari. 1979-911X.

Notonegoro, H. Setyanigsih, I. dan Tarman, K. 2018. Kandungan Senyawa Aktif Spirulina Platensis yang Ditumbuhkan pada Media Walne dengan Konsentrasi Nano berbeda. JPB Kelautan dan Perikanan. 13(2) : 111-122.

Prasadi, Oto. 2018. Pertumbuhan dan Biomassa Spirulina sp. Dalam Media Pupuk sebagai Bahan Pangan Fungsional. Jurnal IImiah Perikanan dan Kelautan. 10(2) : 119-123.

Pandey, J. P., Amit T., Mishra R. M., 2010. Evaluation of Biomass Production of Spirulina maxima on Different Reported Media. Journal Algal Biomass UtIn.

Reynold, C. 2006. Ecology of phytoplankton. England: Cambridge University Press.

Setyaningsih, I. Tarman, K. Satyantini, H, W. dan Barus, A. D. 2013. Pengaruh Waktu Panen dan Nutrisi Media terhadap Biopigmen Spirulina platensis. Jurnal Pengolahan Hasil Perikanan Indonesia. 16(3).

Sirait, S, P. Setyaningsih, I. dan Tarman, K. 2019. Aktivitas Antikanker Ekstrak Spirulina yang Dikultur pada Media Walne dan Media Organik. Jurnal Pengolahan Hasil Perikanan Indonesia. 22(1) : 50-5.

Sutomo. 2005. Kultur tiga jenis mikroalga dan pengaruh kepadatan awal terhadap pertumbuhan Chaetoceros gracilis di laboratorium. Oseanologi dan Limnologi Indonesia. 37:43-58.

Suminto. 2009. Penggunaan Jenis Media Kultur Teknis Terhadap Produksi dan Kandungan Nutrisi Sel Spirulina 
platensis. Jurnal Saintek Perikanan. 4(2) : 53-61.

Tangguh. 2011. Uji Pengaruh Variasi Media Kultur Terhadap Tingkat Pertumbuhan Dan Kandungan Protein Lipid Klorofil Dan Karotenoid Pada Mikroalga Chlorella Vulgaris Buitenzorg. Depok: Fakultas Teknik Universitas Indonesia.

Tokusoglu, Ö. \& M.K. Ûunal. 2006. Biomass Nutrient Profile of Three Microalgae: Spirulina platensis, Chlorella vulgaris and Isochrisis galbana. Journal Food Sci. 86(4): 1144 $-1148$.

Utomo, NBP. Winarti dan Erlina, A. 2005. Pertumbuhan Spirulina platensis yang dikultur dengan pupuk Inorganik (Urea, TSP dan ZA) dan kotoran Ayam. Jurnal akuakultur Indonesia. 4 (1): 41 48.
Venkataraman, L. V. 1983. A Monograph on Spirulina platensis Biotechnology and Aplication. Central Food Technology Research Institute. Mysore, India.

Vonshak, Avigad. 2002. Spirulina platensis (Arthrospira) Physiology, Cell-Biology and Biotechnology. Taylor and Francis. UK.

Wahyuni, N. Masithah, D. E. Soemarjati, W. Suciyono. dan Ulkhaq, F. M. 2018. Pola Pertumbuhan Mikroalga Spirulina $s p$. Skala Laboratorium yang Dikultur Menggunakan Wadah yang Berbeda. 16(2) : 89-97.

Widianingsih, Ali Ridho, Retno Hartati, dan Harmoko, 2008, 'Kandungan Nutrisi Spirulina platensis yang Dikultur pada Media yang Berbeda. Jurnal IImu Kelautan. 3 (13) : 167- 17 